\title{
Secretion and Distribution of lodine-131 in Milk from Dairy Cow after Intravenous Administration of a Single Dose
}

\author{
Yoichiro Онмомо and Masamichi SaIKI \\ Division of Environmental Contamination, National Institute \\ of Radiological Sciences, Chiba, Japan \\ Received April 13, 1970
}

\begin{abstract}
Experiment was carried out in order to know the distribution of ${ }^{131} \mathrm{I}$ in milk and the secretion into milk from lactating Holstein cows after a single intravenous administration. It was recognized that about $26 \%$ and $61 \%$ of dosed ${ }^{131} \mathrm{I}$ was recovered during the 6 days following administration from milk of Holstein $(A)$ and $(B)$ respectively.

About $2 \%$ and $20 \%$ of ${ }^{131} \mathrm{I}$ were found in fat and protein fractions respectively and no regular variation was observed on the distribution pattern as a function of time after administration.

From those considerations it was concluded that Glascock's assumption would be accept able and consequently the composite system of ion exchange treatment and $\mathrm{CCl}_{4}$ extraction would be also acceptable as a rapid and convenient method for the determination of ${ }^{131} \mathrm{I}$ in milk previously recommended by the authors.
\end{abstract}

\section{Introduction}

In previous report ${ }^{1)}$, ion exchange treatment followed by $\mathrm{CCl}_{4}$ extraction was recommended as a rapid method for the determination of ${ }^{131} \mathbf{I}$ in milk. Only an ionic form of iodine could be determined by this method. If the percentage of it is not so variable as suggested by Glascock ${ }^{2)}$, it will be accepted as a rapid and convenient one. Because o the requirement to establish his suggestion, this experiment was carried out in order to know the distribution of ${ }^{131} \mathrm{I}$ in milk and also the secretion of it into milk from lactating Holstein cows after intravenous administraftion of a single dose.

\section{Procedure}

\section{$2 \cdot 1$ Cows}

Two lactating Holstein cows were used. As a preliminary breeding, they were kept in a room, specially designed for a tracer experiment, for about two weeks before administration. In advance, the milk properties such as gravity, $\mathrm{pH}$, acidity, chlorine and lactose contents, and alcohol test were examined in accordance with a usual analytical procedure $^{3)}$

2.2 Preparation of the stock solution and

\section{administration}

Original $\mathrm{Na}^{131} \mathrm{I}$ solution was diluted with $10 \mathrm{~m} l$ of physiological solution of sodium chloride (no carrier was added). Eight $\mathrm{m} l$ (2 $\mathrm{mCi}$ ) and three $\mathrm{ml}(0.75 \mathrm{mCi})$ of the solution were injected to each cow intravenously.

2.3 Milking, fractionation and measurement

Milking was done twice a day in the morning and in the evening. In every milking time, total quantity of the secreted milk and the activity were checked. Fat, protein and whey were separated from every milk and counted. Fat was separated by Roese-Gottlieb method $^{3)}$. Protein was separated by following

Table 1 General analysis of milk

\begin{tabular}{l|c|c|c}
\hline $\begin{array}{r}\text { Milk comes } \\
\text { from }\end{array}$ & $\begin{array}{c}\text { Holstein } \\
\text { (A) }\end{array}$ & $\begin{array}{c}\text { Holstein } \\
\text { (B) }\end{array}$ & $\begin{array}{c}\text { Normal } \\
\text { milk }^{5}\end{array}$ \\
\hline Items & 1.031 & 1.030 & $1.027-1.035$ \\
Gravity & 0.11 & 0.15 & $0.15-0.18$ \\
Acidity(\%) & 0.19 & 0.11 & less than \\
Chlorine (\%) & 4.11 & 4.57 & 4.50 \\
Lactose(\%) & $(-)$ & $(-)$ & $(-)$ \\
Alcohol test & $(-)$ \\
\hline
\end{tabular}

Note: Mastitis or abnormal milk often shows high $\mathrm{pH}$ (more than 6.8), high acidity (more than $0.18 \%$ ), high chlorine content (more than $0.12 \%$ ), high chlorine-lactose number* (more than 4.00) and ( + ) of alcohol test.

* Chlorine-lactose number: chlorine $(\%) \times$ 100/lactose (\%). 
four ways :

a) by addition of rennet,

b) by addition of $1 \mathrm{~N} \mathrm{HCl}$ solution,

c) by addition of $17 \%$ of $\mathrm{TCA}$ solution (trichloroacetic acid)

and d) by ultra high speed centrifugation.

After separation, the radioactivity of the separated whey was measured. Iodine-131 in protein was calculated by subtracting the activities of whey and fat from that of the whole milk used.

\section{Results and Discussions}

The milk properties examined in advance were shown in Table 1. High pH, high chlorine and low lactose contents of milk from Holstein (A) suspected that the milk should be mastitis milk, on the other hand, the low acidity and alcohol test $(-)$ suggested that it might be normal. Anyway it was considered that Holstein (A) was under suspicion of mastitis and therefore chlorotetracycline was

Table 2 The secretion of ${ }^{131} \mathrm{I}$ into milk

\begin{tabular}{|c|c|c|c|c|c|}
\hline Cow & Date of milking & $\begin{array}{l}\begin{array}{l}\text { Quantity of } \\
\text { secreted milk } \\
(\mathrm{kg})\end{array} \\
\end{array}$ & $\begin{array}{l}\text { Concentration of } \\
{ }^{131} \mathrm{(}(\mu \mathrm{Ci})\end{array}$ & $\begin{array}{l}\text { Percentage* } \\
\text { secretion of }{ }^{131} \mathrm{I}\end{array}$ & $\begin{array}{l}\text { Cumulative } \\
\text { percentage } \\
\text { secretion }\end{array}$ \\
\hline \multirow{19}{*}{ Holstein (A) } & 25 Oct. (E)** & 6.0 & 14.58 & 4.6 & 4.6 \\
\hline & $(M)^{* * *}$ & 12.6 & 9.36 & 6.2 & 10.8 \\
\hline & (E) & 4.9 & 9.54 & 2.5 & 13.3 \\
\hline & (M) & 11.1 & 6.60 & 3.8 & 17.1 \\
\hline & (E) & 5. 0 & 6.58 & 1.7 & 18. 8 \\
\hline & (M) & 10. 4 & 3. 81 & 2.1 & 20.9 \\
\hline & (E) & 5.0 & 4. 30 & 1.1 & 22.0 \\
\hline & (M) & 12. 2 & 2. 11 & 1.4 & 23. 4 \\
\hline & (E) & 4.8 & 2. 27 & 0.6 & 24.0 \\
\hline & (M) & 11.4 & 1.72 & 1.0 & 25.0 \\
\hline & (E) & 4.1 & 2. 06 & 0.4 & 25.4 \\
\hline & (M) & 10.7 & 1.22 & 0.7 & 26.1 \\
\hline & (E) & 5.3 & 1.32 & 0.4 & 26.5 \\
\hline & 1 Nov.(M) & 10.6 & 0.84 & 0.5 & 27.0 \\
\hline & (E) & 4.6 & 0.91 & 0.2 & 27.2 \\
\hline & (M) & 11.6 & 0.72 & 0.4 & 27.6 \\
\hline & (E) & 5.0 & 0.80 & 0.2 & 27.8 \\
\hline & (M) & 10.5 & 0.56 & 0.3 & 28.1 \\
\hline & (E) & 6.7 & 0.68 & 0.2 & 28.3 \\
\hline \multirow{12}{*}{ Holstein (B) } & 23 Nov.(E) & 3.0 & 16.57 & 11.4 & 11.4 \\
\hline & $24 \quad(\mathrm{M})$ & 9.3 & 8.64 & 18.4 & 29.8 \\
\hline & $24 \quad(E)$ & 4.7 & 6.15 & 6.6 & 36.4 \\
\hline & (M) & 10.7 & 3.93 & 9.6 & 46.0 \\
\hline & (E) & 4.1 & 3. 44 & 3.2 & 49.2 \\
\hline & (M) & 9.7 & 2.31 & 5.1 & 54.3 \\
\hline & (E) & 4.2 & 1.56 & 1.5 & 55.8 \\
\hline & (M) & 10.6 & 0.93 & 2.2 & 58.0 \\
\hline & (E) & 3.7 & 0.72 & 0.6 & 58.6 \\
\hline & (M) & 10.6 & $0 . \overline{51}$ & 1.2 & 59.8 \\
\hline & (E) & 3.8 & 0.38 & 0.3 & 60.1 \\
\hline & (M) & 10.7 & 0.29 & 0.7 & 60.8 \\
\hline
\end{tabular}

* Secreted ${ }^{131} \mathrm{I} \times 100 /$ administered ${ }^{131} \mathrm{I}$

** Evening

*** Morning 
administered to it. Table 2 shows the secretion of ${ }^{131} \mathrm{I}$ into milk.

The highest concentration of ${ }^{131} \mathrm{I}$ shown as ${ }^{131} \mathrm{I} \mu \mathrm{Ci} / l$ of milk was observed four hours after intravenous administration. This suggested that the transfer velocity from blood to milk was considerably fast. The quantity of the morning milk was generally more than that of the evening milk, but the concentration of ${ }^{131} \mathbf{I}$ was higher in the evening milk than in the morning milk, presumably caused by the difference of the milking interval. Maximum secretion of ${ }^{131} I$ was observed on the second day after administration.

About $26 \%$ and $61 \%$ of ${ }^{131} \mathrm{I}$ were recovered during the 6 days following a single intravenous administration from Holstein (A) and Holstein (B) respectively. Those are considerably high compared with 1.3 to $13.1 \%$ (mean: $5 \%$ ) recovery from milk of cows during the 6 days following a single oral dose reported by Garner ${ }^{4}$. In this case of oral administration, high percentage of ${ }^{131}$ I should be excreted directly to feces to result in less percentagetransference to milk. Iodine absorbed by cows is deposited mainly in thyroid gland which is the critical organ for ${ }^{131} \mathrm{I}$. It is said that the transfer rate of dosed ${ }^{131} I$ to thyroid gland can be influenced by the level of stable iodine in blood, consequently by the amount of stable iodine in feed. And it is conjectured that the secretion rate of ${ }^{131}$ I to milk may be fluctuated against the variation of the transfer rate of ${ }^{131}$ I to thyroid gland. This suggests that the saturation of thyroid gland with stable iodine may cause the decrease of the transfer rate of dosed ${ }^{131} \mathrm{I}$ to thyroid gland, and consequently the increase of ${ }^{131} \mathrm{I}$ to milk. Hight recovery of ${ }^{131} \mathrm{I}$ obtained may be due to an intravenous administration and also partially due to the reason mentioned above because cows were fed by the formula feed containing $5 \%$ of fish meal whose iodine content should be high.

Table 3 shows the distribution of ${ }^{131} I$ in milk. Only two percent of iodine was found in fat fraction. Percentage of the distribution to protein, which was somewhat variable by the method of the separation, was about $20 \%$ as shown in Table 3. Ultra high speed centrifugation showed the considerably low concentration

Table 3 Distribution of ${ }^{131} \mathrm{I}$ in milk collected in the morning

\begin{tabular}{|c|c|c|c|c|c|c|}
\hline \multirow{3}{*}{ Cows } & \multirow{3}{*}{ Date of milking } & \multicolumn{5}{|c|}{ Percentage of distribution } \\
\hline & & \multirow{2}{*}{ Fat fraction } & \multicolumn{4}{|c|}{ Protein fraction separated by } \\
\hline & & & rennet & $1 N \mathrm{HCl}$ & TCA & UHC* \\
\hline \multirow{7}{*}{ Holstein(A) } & 26 Oct. & 0 & 27 & 16 & 27 & 2 \\
\hline & 27 & 0 & 21 & 25 & 17 & 3 \\
\hline & 28 & 0 & 17 & 20 & 19 & \\
\hline & 29 & 5 & 34 & 25 & 16 & \\
\hline & 30 & 1 & 33 & 22 & 31 & \\
\hline & 31 & 7 & 28 & 20 & 30 & \\
\hline & Average & 2 & 27 & 21 & 23 & 3 \\
\hline \multirow{5}{*}{ Holstein(B) } & 24 Nov. & 0 & 19 & 22 & 13 & 4 \\
\hline & 25 & 1 & 24 & 21 & 一 & 8 \\
\hline & 26 & 5 & 31 & 22 & 19 & \\
\hline & 27 & 0 & 28 & 19 & 12 & \\
\hline & Average & 2 & 26 & 21 & 15 & 6 \\
\hline \multirow{2}{*}{\multicolumn{2}{|c|}{$\begin{array}{l}\text { Total average } \\
\text { Standard deviation }\end{array}$}} & 2 & 26 & 21 & 20 & 4 \\
\hline & & & 6 & 3 & 7 & \\
\hline
\end{tabular}

Remark: Each value contains at least $15 \%$ errors.

* Ultra high speed centrifugation. 
of ${ }^{131} \mathrm{I}$, suggesting the imperfect separation of protein. Protein fraction separated by rennet showed a little high concentration of ${ }^{131} \mathrm{I}$, presumably caused by intermixture of whey, because the volume of the protein was somewhat more than that of protein coagulated by $1 \mathrm{~N} \mathrm{HCl}$ and 17\% TCA. From those considerations it was estimated that about $20 \%$ of ${ }^{131}$ I combined with protein.

Because of the short half life of ${ }^{131} \mathrm{I}$, it is not necessary to consider the contamination of ${ }^{131} \mathbf{I}$ into milk products such as butter and cheese. But in case of ${ }^{129} \mathrm{I}$, the contamination of it into milk products cannot be always ignored because of the long half life of $1.7 \times 10^{7}$ years. As mentioned above, in that case, nearly $30 \%$ of ${ }^{129} \mathrm{I}$ should be contained in cheese, because cheese is coagulated mostly by rennet.

No regular variation was observed on the distribution pattern as a function of time after administration.

It was concluded that Glascock's assumption would be supported through those experiments and consequently the composite system of ion exchange treatment and $\mathrm{CCl}_{4}$ extraction would be acceptable as a rapid and convenient method for the determination of ${ }^{131} \mathbf{I}$ in milk previously recommended by the authors.

\section{Conclusion}

Experiment was carried out in order to know the distribution of ${ }^{131} \mathbf{I}$ in milk and the secretion into milk from lactating Holstein cows after a single intravenous administration. It was recognized that about $26 \%$ and $61 \%$ of dosed ${ }^{131} \mathrm{I}$ was recovered during the 6 days following administration from milk of Holstein (A) and (B) respectively.

About $2 \%$ and $20 \%$ of ${ }^{131} \mathrm{I}$ were found in fat and protein fractions respectively and no regular variation was observed on the distribution pattern as a function of time after administration.

From those considerations it was concluded that Glascock's assumption would be acceptable and consequently the composite system of ion exchange treatment and $\mathbf{C C l}_{4}$ extraction would be also acceptable as a rapid and convenient method for the determination of ${ }^{131} \mathbf{I}$ in milk previously recommended by the authors.

\section{Acknowledgement}

Authors wish to express their heartfelt thanks to Dr. H. Danbara and Mr. S. Miyamoto, National Institute of Animal Industry, for their useful advice and kind help, also wish to express their thanks to Miss H. Yamaguchi for her kind help.

\section{References}

1) Y. Ohmomo and M. Saiki: Radioisotepes, 13, (4) 304 (1964)

2) R.F.Glascock: J.Dairy Res., 21, 318(1954)

3) The Welfare Ministry: Eisei kensa shishin (III), Shyokuhin eisei kensa shishin (1), Kyodo Medical Publishing Co. Ltd., (1960)

4) R.J. Garner and B. F. Sanson: Vet. Record, 71, 67 (1959)

5) R. Sasaki and T. Tsugo: Chichi no Kagaku (Chemistry of Milk), Chikyu Publishing Co. Ltd., (1957)

静脈内投与した ${ }^{131}$ | の乳汁への分泌ならびに乳における分布

\author{
大桃洋一郎, 佐伯誠道 \\ 放射線医学総合研究所, 環境污染研究部
}

\begin{abstract}
静脈内投与した ${ }^{131} \mathrm{I}$ の乳汁への分泌ならびに乳における分布について検討した。乳牛としては ホルシュタイン牛 2 頭を用い, $\mathrm{Na}^{131} \mathrm{I}$ を静脈内に 1 回投与した。投与後 6 日間に, 乳中に分泌さ れた ${ }^{131} \mathrm{I}$ の量は，投与量のそれぞれ $26 \%$ および $61 \%$ 市った。乳中に分泌された ${ }^{131} \mathrm{I}$ のち約 2 \%が脂肪区分に，約 $20 \%$ ダンパク区分に見出された。牛乳中の ${ }^{131} \mathrm{I}$ の分布状態については，投与 後の経時的規則的変動は見出されなかった。本実験により, Glascock の仮説が支持され, 著者ら が以前本紙に投稿した牛乳中の ${ }^{131} \mathrm{I}$ の迅速定量法が，実用に供しうることが判明した。
\end{abstract}

